\title{
ANALISIS YURIDIS TERHADAP E - PURCHASING DALAM PENGADAAN BARANG/JASA PEMERINTAH
}

\author{
Iwan Kurniawan* \\ Kantor Wilayah Kementerian Hukum dan \\ Hak Asasi Manusia Kepulauan Riau
}

\begin{abstract}
Procurement of Government Goods \& Services is an activity to obtain goods and services by Ministries, Institutions, Regional Work Units, other Institutions. Procurement of government goods / services electronically can be done through e-tendering or e-purchasing. With the procurement of goods and services, the government opens opportunities as well as challenges for Indonesian entrepreneurs, including Micro, Small and Medium Enterprises. The government should take an important role in supporting Micro, Small and Medium Enterprises with efforts to foster a conducive business climate for businesses and support the development of Micro, Small and Medium Enterprises.
\end{abstract}

Keywords: Micro and Small and Medium Enterprises, E-Purchasing.

\begin{abstract}
Abstrak
Pengadaan Barang dan Jasa Pemerintah merupakan aktivitas dalam rangka mendapatkan barang dan jasa oleh Kementerian, Lembaga, Satuan Kerja Perangkat Daerah, Institusi lainnya.Pengadaan barang/jasa pemerintah secara elektronik dapat dilakukan melalui eTendering atau $e$-Purchasing.Dengan adanya pengadaan barang dan jasa pemerintah membuka peluang sekaligus tantangan bagi pengusaha Indonesia termasuk Usaha Mikro, Kecil dan Menengah.Pemerintah seharusnya mengambil peran yang penting dalam mendukung Usaha Mikro, Kecil dan Menengah dengan upaya untuk menumbuhkan iklim berusaha yang kondusif bagi pelaku usaha dan memberi dukungan terhadap berkembangnya Usaha Mikro, Kecil dan Menengah.
\end{abstract}

Kata Kunci : Usaha Mikro Kecil dan Menengah, E - Purchasing.

\section{A. Latar Belakang Masalah}

Pengadaan Barang dan Jasa Pemerintah merupakan aktivitas dalam rangka mendapatkan barang dan jasa oleh Kementerian, Lembaga, Satuan Kerja Perangkat Daerah, Institusi lainnya yang prosesnya dimulai dari perencanaan kebutuhan sampai dengan diselesaikannya seluruh kegiatan untuk memperoleh barang dan jasa. Prosedur mengenai tata cara pengadaan barang dan jasa dalam Peraturan Presiden Nomor 16 Tahun 2018 tentang Pengadaan Barang/Jasa Pemerintah diharapkan dapat meningkatkan iklim investasi yang kondusif, efisiensi belanja negara, dan percepatan pelaksanaan APBN/APBD. Selain itu Pengadaan Barang dan Jasa Pemerintah yang berpedoman pada Peraturan

*Alamat korespondensi : aprilduapuluhenam@gmail.com 
Presiden ini ditujukan untuk meningkatkan keberpihakan terhadap industri nasional.

Pengadaan barang/jasa pemerintah pada pelaksanaannya dapat dilakukan secara elektronikmelalui E-Tendering atau E-Purchasing.Dengan adanya pengadaan barang/jasa pemerintah membuka peluang sekaligus tantangan bagi pengusaha Indonesia termasuk Usaha Mikro, Kecil dan Menengah.Usaha Mikro, Kecil dan Menengah merupakan amanat Undang-Undang Dasar Negara Republik Indonesia Tahun 1945 yang harus diwujudkan melalui pembangunan perekonomian nasional berdasarkan demokrasi ekonomi. Dalam Undang-Undang Nomor 20 Tahun 2008 tentang Usaha Mikro Kecil dan Menengah, pemberdayaan Usaha Mikro, Kecil dan Menengah diselenggarakan secara menyeluruh, optimal dan berkesimbugan serta memperoleh jaminan kepastian dan keadilan usaha.

Usaha Mikro, Kecil dan Menengah nasional banyak mengalami masalah, khususnya dalam bidang manajemen, baik manajemen produksi, pemasaran, maupun sumber daya manusia serta masalah pembiayaan. Dalam kaitannya dengan pengadaan barang/jasa pemerintah, Usaha Mikro Kecil dan Menengah sangat sulit untuk bersaing dari pelaku bisnis raksasa yang notabene memiliki mesin produksi yang kuat serta modal yang besar.Acap kali pelaku Usaha Mikro, Kecil dan Menengah tidak mampu bersaing dengan usaha besar karena terkendala persoalan-persoalan pendanaan dan sumber daya manusia.

Berdasarkan permasalah tersebut, maka peneliti tertarik untuk melakukan penelitian tentang "ANALISIS YURIDIS TERHADAP $E-P U R C H A S I N G$ DALAM PENGADAAN BARANG/JASA".

\section{B. Perumusan Masalah}

1. Apakah Peraturan Presiden Nomor 16 Tahun 2018 tentang Pengadaan Barang/Jasa Pemerintah memberikan pengaturan tentang kesempatan UMKM dalam sistem $e$ - purchasing?

2. Bagaimana peran negara dalam memberikan perlindungan hukum bagi usaha mikro, kecil dan menengah?

\section{Metode Penelitian}

Penelitian yang ditujukan untuk menganalisis permasalahan yang dirumuskan diatas, dilakukan dengan metode pendekatan Yuridis Normatif.Penelitian hukum normatif atau penelitian perpustakaan ini merupakan penelitian yang mengkaji studi dokumen, yakni menggunakan berbagai data sekunder seperti seperti peraturan perundang-udangan, keputusan pengadilan, teori hukum, dan dapat berupa pendapat para sarjana.Penulis akan melakukan penelitian dengan mengambil beberapa ide dari Peter Mahmud namun sebagian besar akan mengikuti pola umum yang banyak dilakukan di sekolah hukum di Indonesia dengan tetap mengacu pada pola penelitian dalam studi politik hukum.

Kegiatan yang dilakukan dalam pengumpulan data dalam penelitian ini yaitu dengan cara mengumpulkan (dokumentasi) data sekunder berupa pendapat para 
ahli, tulisan-tulisan dalam buku ilmiah, dokumen, arsip, literatur, makalah, dan bahan kepustakaan lainnya yang berhubungan erat dengan masalah yang penulis teliti.Peneliti melakukan studi dokumen terhadap buku-buku dan literatur-literatur yang berhubungan dengan penelitian ini untuk memperoleh landasan teoritis yang dapat digunakan untuk menganalisis perlindungan hokum terhadap usaha mikro kecil dan menengah.

Data yang diperoleh dalam penelitian ini dianalisis secara yuridis kualitatif dengan menggunakan metode berpikir deduktif (umum-khusus), yaitu dengan menjabarkan, menafsirkan dan mengkonstruksikan data yang diperoleh berdasarkan norma-norma atau kaidah-kaidah, teori-teori, pengertian-pengertian hukum dan doktrin-doktrin yang ada dalam dokumen, Peraturan Perundangundangan, untuk menjawab permasalahan yang ada. Analisis data dilakukan secara bertahap, sehingga kekurangan data penelitian secepatnya dapat diketahui dan sesegera mungkin dilengkapi dengan melakukan penelitian ulang guna pengambilan data tambahan untuk melengkapi kekuarangan data tersebut.

Penelitian kepustakaan yang dilakukan adalah membandingkan peraturanperaturan, ketentuan-ketentuan, dan buku referensi, serta data yang diperoleh, kemudian dianalisis secara kualitatif yang akan memberikan gambaran menyeluruh tentang aspek hukum yang berhubungan dengan masalah yang akan diteliti.Pada garis besarnya penelitian ini mengambil metode sebagai berikut:

1. Pendekatan penelitian.

a. Statute approach: untuk menelaah peraturan perundang-undangan yang berlaku dengan fokus pada UU Usaha Mikro, Kecil dan Menengah dibandingkan dengan peraturan perundangan-undangan lain dengan hirarki sederajat dan di atasnya,

b. Conceptual Approach: untuk menelaah isu hukum atau gejala yang timbul dianalisa dengan teori hukum yang dijadikan pisau analisis.

2. Diuraikan secara kualitatif.

a. Variable-variable dianalisa dengan menggunakan teori yang obyektif.

b. Pola-pola yang dianalisa adalah gejala-gejala masyarakat yang ditimbulkan oleh pemberlakuan suatu peraturan hukum.

c. Interpretasi menurut bahasa yaitu suatu penafsiran yang didasarkan atas arti dari suatu kata atau bahasa.

d. Interpretasi sistematis yaitu suatu penafsiran yang dilakukan dengan menghubungkan satu sumber hukum dengan sumber hukum lainnya.

e. Interpretasi historis yaitu suatu penafisran yang dilakukan dengan cara menganalisa sejarah suatu aturan perundang-undangan.

f. Interpretasi komparatif yaitu suatu penafsiran yang dilakukan dengan cara membanding berbagai sumber hukum.

g. Argumentum per analogiam yaitu suatu penafisiran yang dilakukan melalui suatu cara analogi.

Berdasarkan penguraian di atas, penulis akan menganalisis hasil pengumpulan data secara kualitiatif yang akan menjelaskan tentang : 
a. Menganalisi dan menemukan pengaturan tentang kesempatan UMKM dalam sistem $e$-purchasing pada Peraturan Presiden Nomor 16 Tahun 2018 tentang Pengadaan Barang/Jasa Pemerintah

b. Menganalisis dan menemukan peran negara dalam memberikan perlindungan hukum bagi usaha mikro, kecil dan menengah.

\section{Hasil Penelitian dan Pembahasan}

Pergaulan antar manusia sebagai anggota masyarakat saling mempunyai kepentingan. Kepentingan tersebut ada yang sama dan ada yang bertentangan antara satu sama lain. Dalam konteks pertentangan kepentingan masyarakat ini akan menimbulkan persoalan wajar dan tidak wajar, patut dan tidak patut, yang pada akhirnya pertentangan kepentingan ini dapat melanggar hak asasi manusia. Menurut teori konvensional, tujuan hukum adalah mewujudkan keadilan (rechtgerechtigheid), kemanfaatan (rechtsutiliteit) dan kepastian hukum (rechtszekerheid). Dalam hal mewujudkan keadilan, Adam Smith (1723-1790), Guru Besar dalam bidang filosofi moral dan sebagai ahli teori hukum dari Glasgow University pada tahun 1750 telah melahirkan ajaran mengenai keadilan(justice). Smith mengatakan bahwa: "tujuan keadilan adalah untuk melindungi diri dari kerugian" (the end of justice is to secure from injury).

Pembangunan nasional bertujuan untuk mewujudkan masyarakat adil dan makmur yang merata material dan spiritual berdasarkan Pancasila dan Undang-Undang Dasar Negara Republik Indonesia Tahun 1945 dalam wadah Negara Kesatuan Republik Indonesia. Pembangunan nasional yang mencakup seluruh aspek kehidupan bangsa diselenggarakan bersama oleh masyarakat dan pemerintah.Masyarakat menjadi pelaku utama pembangunan, dan pemerintah berkewajiban mengarahkan, membimbing, melindungi, serta menumbuhkan suasana dan iklim yang menunjang.

Usaha Mikro, Kecil, dan Menengah merupakan kegiatan usaha yang mampu memperluas lapangan kerja dan memberikan pelayanan ekonomi secara luas kepada masyarakat, dan dapat berperan dalam proses pemerataan dan peningkatan pendapatan masyarakat, mendorong pertumbuhan ekonomi, dan berperan dalam mewujudkan stabilitas nasional. Selain itu, Usaha Mikro, Kecil, dan Menengah adalah salah satu pilar utama ekonomi nasional yang harus memperoleh kesempatan utama, dukungan, perlindungan dan pengembangan seluas-luasnya sebagai wujud keberpihakan yang tegas kepada kelompok usaha ekonomi rakyat, tanpa mengabaikan peranan Usaha Besar dan Badan Usaha Milik Negara.

Dalam perspektif perkembangannya, UKM dapat diklasifikasikan menjadi 4 (empat) kelompok yaitu :

a. Livelihood Activities, merupakan UKM yang digunakan sebagai kesempatan kerja untuk mencari nafkah, yang lebih umum dikenal sebagai sektor informal. Contohnya adalah pedagang kaki lima; 
b. Micro Enterprise, merupakan UKM yang memiliki sifat pengrajin tetapi belum memiliki sifat kewirausahaan;

c. Small Dynamic Enterprise, merupakan UKM yang telah memiliki jiwa kewirausahaan dann mampu menerima pekerjaan subkontrak dan ekspor;

d. Fast Moving Enterprise, merupakan UKM yang telah memiliki jiwa kewirausahaan dan akan melakukan transformasi menjadi Usaha Besar (UB).

Usaha Mikro Kecil dan Menengah merupakan basis ekonomi kerakyatan. Oleh karena itu sangat penting perannya dalam pembangunan ekonomi nasional karena memperluas lapangan kerja dan memberikan pelayanan ekonomi secara luas kepada masyarakat, berperan dalam proses pemerataan dan peningkatan pendapatan masyarakat, mendorong pertumbuhan ekonomi, dan berperan dalam mewujudkan stabilitas Negara.

Salah satu keunggulan UKM adalah, ia terkadang sangat lincah mencari peluang untuk berinovasi untuk menerapkan teknologi baru ketimbang perusahaanperusahaan besar yang telah mapan. Tak mengherankan jika dalam era persaingan global saat ini banyak perusahaan besar yang bergantung pada pemasok-pemasok kecil-menengah.Sesungguhnya ini peluang bagi kta untuk turut berkecimpung di era global sekaligus menggerakkan sektor ekonomi riil.

Perkembangan Usaha Mikro, Kecil dan Menengah di Indonesia tidak terlepas dari berbagai masalah. Beberapa masalah umum yang dihadapi Usaha Mikro, Kecil dan Menengah yaitu keterbatasan modal, kesulitan bahan baku dengan harga terjangkau dan kualitas yang baik, keterbatasan teknologi, sumber daya manusia yang dengan kualitas baik, informasi pasar dan kesulitan pemasaran. Tingkat intensitas dan sifat dari masalah-masalah tersebut bisa berbeda tidak hanya menurut jenis produk, atau pasar yang dilayani, tetapi juga berbeda antar lokasi atau wilayah, sektor atau antar subsektor, antar jenis kegiatan, dan antar unit usaha dalam kegiatan yang sama.

Selain permasalahan diatas, ada beberapa faktor eksternal yang mempengaruhi perkembangan industri kecil menengah,diantaranya sangat terbatasnya fasilitas dalam mengembangkan akses pasar bagi produk-produk industri kecil menengah, kurangnya keterpaduan kebijakan, konsisten, serta komitmen dari para pembuat keputusan dalam mengembangkan usaha kecil dan menengah, terbatasnya dukungan dari lembaga keuangan dalam memberikan pinjaman lunak, belum meluasnya sikap keberpihakan konsumen dalam negeri untuk memilih produk dalam negeri, belum memadainya dukungan infrastruktur terhadap sentra-sentra produksi ndustri kecil menengah seperti dalam hal lahan, listrik, komunikasi, penampungan limbah yang tidak membahayakan lingkungan, serta lemahnya kemitraan dan solidaritas pengusaha besar terhadap pengusaha keci sehingga tidak terciptanya keterkaitan industri antar industri besar dan industri kecil menengah.

Seiring pertumbuhan ekonomi Indonesia yang pesat disertai dengan pengembangan otonomi daerah, kebutuhan pemerintah akan penyelenggaraan pemerintahan turut meningkat. Kebutuhan pemerintah tersebut dapat secara 
materiil maupun non materiil. Kebutuhan tersebut terwakili melalui proses pengadaan barang/jasa.

Pengaturan mengenai tata cara Pengadaan Barang/Jasa Pemerintah diharapkan dapat meningkatkan iklim investasi yang kondusif, efisiensi belanja negara, dan percepatan pelaksanaan APBN/ APBD. Selain itu, Pengadaan Barang/Jasa Pemerintah ditujukan untuk meningkatkan keberpihakan terhadap industri nasional dan usaha kecil, serta menumbuhkan industri kreatif, inovasi, dan kemandirian bangsa dengan mengutamakan penggunaan industri strategis dalam negeri.Kebijakan umum Pengadaan Barang/Jasa Pemerintah bertujuan untuk mensinergikan ketentuan Pengadaan Barang/Jasa dengan kebijakan-kebijakan di sektor lainnya.

Langkah-langkah kebijakan yang akan ditempuh Pemerintah dalam Pengadaan Barang/Jasa sebagaimana diatur dalam Peraturan Presiden Nomor 16 Tahun 2018 tentang Pengadaan Barang/Jasa Pemerintah, meliputi :

a. peningkatan penggunaan produksi Barang/Jasa dalam negeri yang sasarannya;

b. untuk memperluas kesempatan kerja dan basis industri dalam negeri dalam rangka meningkatkan ketahanan ekonomi dan daya saing nasional;

c. kemandirian industri pertahanan, industri alat utama sistem senjata (Alutsista) dan industri alat material khusus (Almatsus) dalam negeri;

d. peningkatan peran serta Usaha Mikro, Usaha Kecil, koperasi kecil dan kelompok masyarakat dalam Pengadaan Barang/Jasa;

e. Perhatian terhadap aspek pemanfaatan sumber daya alam dan pelestarian fungsi lingkungan hidup secara arif untuk menjamin terlaksananya pembangunan berkelanjutan;

f. Peningkatan penggunaan teknologi informasi dan transaksi elektronik;

g. Penyederhanaan ketentuan dan tata cara untuk mempercepat proses pengambilan keputusan dalam Pengadaan Barang/Jasa;

h. Peningkatan profesionalisme, kemandirian, dan tanggung jawab para pihak yang terlibat dalam perencanaan dan proses Pengadaan Barang/Jasa;

i. Peningkatan penerimaan negara melalui sektor perpajakan;

j. Penumbuhkembangan peran usaha nasional;

k. Penumbuhkembangan industri kreatif inovatif, budaya dan hasil penelitian laboratorium atau institusi pendidikan dalam negeri;

1. Memanfaatkan sarana/prasarana penelitian dan pengembangan dalam negeri;

m. Pelaksanaan Pengadaan Barang/Jasa di dalam wilayah Negara Kesatuan Republik Indonesia, termasuk di Kantor Perwakilan Republik Indonesia; dan

n. Pengumuman secara terbuka rencana dan pelaksanaan Pengadaan Barang/Jasa di masing-masing Kementerian/Lembaga/Satuan Kerja Pemerintah Daerah/Institusi lainnya kepada masyarakat luas.

Pengadaan barang/jasa pemerintah pada hakikatnya merupakan upaya pihak pemerintah yang diwakili oleh Pengguna Anggaran untuk mendapatkan barang/jasa yang diinginkan dengan menggunakan metode, proses sesuai dengan ketentuan agar dicapai kesepakatan mengenai harga, waktu dan kualitas barang/jasa. 
Dalam proses pengadaan barang/jasa pemerintah, UMKM memilki peran, antara lain :

a. Dalam Pengadaan Barang/Jasa, PA/ KPA memperluas peran serta usaha kecil;

b. Pemaketan dilakukan dengan menetapkan sebanyak banyaknya paket untuk usaha kecil tanpa mengabaikan prinsip efisiensi, persaingan usaha yang sehat, kesatuan sistem, dan kualitas kemampuan teknis;

c. Nilai paket Pengadaan Barang/Pekerjaan Konstruksi/Jasa Lainnya paling banyak Rp2.500.000.000,00 (dua miliar lima ratus juta rupiah), dicadangkan dan peruntukannya bagi usaha kecil, kecuali untuk paket pekerjaan yang menuntut kemampuan teknis yang tidak dapat dipenuhi oleh usaha kecil;

d. LKPP dan Kementerian/Lembaga/ Pemerintah Daerah memperluas peran serta usaha kecil dengan mencantumkan barang/jasa produksi usaha kecil dalam katalog elektronik.

Sebagaimana diatur dalam Pasal 131 ayat (1) Peraturan Presiden Nomor 54 Tahun 2010 Tentang Pengadaan Barang/Jasa Pemerintah bahwa K/L/D/I wajib melaksanakan pengadaan barang/jasa secara elektronik untuk sebagian/seluruh paket-paket pekerjaan pada Tahun Anggaran 2011. Ketentuan teknis operasional pengadaan barang/jasa secara elektronik mengacu pada Peraturan Kepala LKPP Nomor 2 Tahun 2010 Tentang Layanan Pengadaan Secara Elektronik (LPSE), Peraturan Kepala LKPP Nomor 1 Tahun 2011 Tentang e-Tendering, Peraturan Kepala LKPP Nomor 5 Tahun 2011 Tentang Standar Dokumen Pengadaan Barang/Jasaa Pemerintah Secara Elektronik. Terhadap informasi, transaksi elektronik pada pelaksanaan pengadaan barang/jasa pemerintah secara elektronik mengacu pada Undang-undang nomor 11 tahun 2008 tentang ITE.

Pengadaan barang/jasa pemerintah secara elektronik (e-procurement) dapat dilakukan dengan e-Tendering atau e-Purchasing.e-Tendering merupakan tata cara pemilihan penyedia barang/jasa yang dilakukan secara terbuka dan dapat diikuti oleh semua penyedia barang/jasa yang terdaftar pada sistem pengadaan elektronik dengan cara menyampaikan satu kali penawaran dalam waktu yang telah ditentukan. Sedangkan e-Purchasing merupakan tata cara pembelian barang/jasa melalui sistem katalog elektronik.E-Tendering tersebut dilaksanakan dengan menggunakan Sistem Pengadaan Secara Elektronik yang diselenggarakan oleh Layanan Pengadaan Secara Elektronik.

Manfaat dari e-procurement dapat dirasakan oleh rekanan dan juga pemerintah.Bagi rekanan, mereka tidak perlu bolak-balik untuk memberikan keterangan berkas-berkas terkait yang dibutuhkan serta tidak perlu memfotokopi berkas-berkas.Jika ada masalah atau hal-hal yang masih belum dimengerti, rekanan bisa chatting dengan petugas untuk mempertanyakan semua hal terkait dengan pengadaan. Selain itu, rekanan cukup datang sekali ke LPSE untuk mendapatkan account number yang akan digunakan untuk mengikuti lelang. Setelah itu, pengiriman berkas dapat dilakukan di rumah tanpa harus datang ke LPSE.

Sedangkan manfaat untuk pemerintah adalah bisa mendapatkan barang/jasa yang lebih kompetitif dan berkualitas dengan adanya pengadaan lelang secara 
elektronik.Selain itu, pemerintah juga mendapatkan keuntungan terkait praktik transparansi dan akuntabilitas pelayanan.Dengan adanya e-procurement ini kinerja pemerintah dalam proses pengadaan barang/jasa cenderung lebih efektif dan efisien daripada melalui cara manual. E-procurement ini juga dapat mencegah praktek korupsi yang sering terjadi pada pengadaan barang/jasa karena antara petugas dan rekanan tidak dapatbertemu langsung.Hal ini menghalangi rekanan maupun petugas untuk bermain curang dalam penentuan pemenang pengadaan barang/jasa.

Pengadaan barang jasa Pemerintah yang bersih menggunakan E-purchasing menjadi jalan keluar untuk membantu pemberantasan korupsi.E-purchasing yang menggunakan e-catalogue sangat menyulitkan para oknum termasuk penyedia yang ingin berlaku curang. Harga dan spesifikasi teknis serta merk dan yang telah tertera akan sangat menyulitkan untuk mengelabui dengan melakukan markup harga. Untuk penyedia yang terdaftar di e-catalogue telah dilakukan verifikasi yang ketat oleh LKPP selaku institusi yang mengelola e-catalogue. LKPP telah membuat suatu data base tentang penyedia yang handal yaitu Sistem Informasi Kinerja Penyedia (SIKAP). Dari Sistem Informasi Kinerja Penyedia (SIKAP) ini dapat diketahui performance penyedia dalam aktifitas pengadaan barang jasa Pemerintah dan tentunya penyedia akan selalu menjaga kinerja dan nama baik agar tetap ikut serta dalam pembangunan Indonesia.E-Purchasing sejatinya adalah bagian dari kebijakan penyederhanakan aturan dan tata cara yang sudah barang tentu tidak ditujukan untuk menggantikan posisi pelelangan/seleksi umum sebagai implementasi prinsip-prinsip pengadaan barang/jasa.

Dilihat dari jumlah dan variannya, produk-produk di e-katalog mengalami peningkatan yang sangat signifikan. Pertama kali diperkenalkan tahun 2012 dengan hanya memuat puluhan produk kendaraan bermotor roda empat, kini jumlahnya melebihi 60 ribu produk dengan nilai transaksi lebih dari 76 triliun. Angka ini dipercaya akan terus meningkat seiring dengan kebutuhan belanja pemerintah seiring perkembangannya, sejumlah tantangan dihadapi oleh LKPP.

E-purchasing memiliki banyak keunggulan dan kemudahan yang ditawarkan. Selain bebas prosedural yang rumit, personil yang ditugaskan untuk melaksanakan pengadaan akan lebih mudah dalam pelaksanaannya. Tidak perlu proses lelang yang panjang, karena sudah tersusun secara elektronik. Tidak perlurepot menyusun Harga Perkiraan Sendiri (HPS) karena tinggal membeli barang atau jasa yang tertera di katalog sesuai dengan harga yang sudah terpublikasikan. Selain itu harga barang atau jasa yang dipublikasikan dapat dipertanggungjawabkan, bahkan lebih murah dari harga pasaran secara umum.

E-purchasing pastinya akan menutup peluang terjadinya pelelangan gagal, karena produsen barang atau jasa yang tercantum di dalam katalog sudah menjamin akan ketersediaan barang atau jasa yang ditawarkan berikut dengan harganya. Adanya kemudahan dan keunggulan inilah yang menyebabkan terbukanya peluang bagi penyedia barang atau jasa khususnya yang bertindak sebagai produsen, dengan terdaftar dalam katalog elektronik maka penyedia barang atau jasa secara 
langsung mempromosikan produk mereka secara gratis kepada seluruh instansi pemerintah (K/L/D/I) yang ada di Indonesia.

E-Purchasing merupakan proses pengadaan barang dan jasa pemerintah yang dilakukan secara elektronik terutama berbasis web atau internet. Instrumen ini memanfaatkan fasilitas teknologi komunikasi dan informasi meliputi pemilihan penyedia secara elektronik yang diselenggarakan oleh LPSE. Kebijakanimplementasi E-Procurement dilakukan dengan cara mengoptimalkan pemanfaatan kemajuan teknologi informasi untuk mewujudkan good governance melalui pengadaan barang dan jasa yang bebas KKN. Sasaran diterapkanya sistem E-Procurement adalah untuk memberikan media proses pengadaan barang yang transparan, kompetitif, efektif, efisien, adil dan tidak diskriminatif dan akuntabel. Namun dibalik kecanggihan dalam pengadaan barang dan jasa melalui $E$ Purchasing ada sisi lain yang perlu mendapatkan perhatian, yaitu kemampuan pelaku Usaha Mikro, Kecil dan Menengah dalam berkompetisi di sistem katalog elektronik.Kekurangan dalam hal pemodalan, tenaga kerja dan bahan baku membuat Usaha Mikro, Kecil dan Menengah akan sangat sulit bersaing dengan pebisnis raksasa dalam hal penentuan harga suatu produk. Kemampuan sumber daya yang kuat dari perusahaan-perusahaan besar, memberikan implikasi terhadap rendahnya harga yang ditawarkan perusahaan-perusahaan besar tersebut.

Akumulasi modal merupakan ukuran yang digunakan untuk melihat proses yang menandai berkembang atau tidaknya suatu unit usaha. Di dalam Usaha Mikro, Kecil dan Menengah, pengertian akumulasi modal tersebut tidak hanya diukur dari adanya peningkatan skala usaha tetapi juga dapat dilihat melalui adanya peningkatan kesejahteraan bangsa.Hanya saja perlu diamati apakah bentuk-bentuk peningkatan usaha maupun kesejahteraan keluarga tersebutmerupakan sumbangan dari usaha yang bersangkutan ataukah disebabkan adanya subsidi dari pendapatan lainnya. Secara umum Usaha Mikro, Kecil dan Menengah tidak dapat mengakumulasi modal dibandingkan pelaku-pelaku usahalainnya yang lebih besar di jalur penyediaan bahan baku, jalur pemasaran produk, dan jalur pemodalan. Terdapat pola relasi yang mengeksploitasi kelompok-kelompok pelaku Usaha Mikro, Kecil dan Menengah.Pada setiap pelaku usaha di dalam rantai komoditas dan pola-pola eksploitatif yang menjadi penyebab adanya perbedaan kemampuan akumulasi modal tersebut.

Rantai hulu hilir Usaha Mikro, Kecil dan Menengah terdapat hubungan eksploitatif yang menyebabkan sekelompok pelaku Usaha Mikro, Kecil dan Menengah tidak dapat mengakumulasi modal. Relasi eksploitatif dapat terjadi ketika sekelompok orang atau pelaku memiliki kekuasaan atau privilege yang lebih besar dibandingkan pihak lain, sehingga pelaku yang bersangkutan dapat menentukan aturan main dan kondisi hubungan yang menguntungkan dirinya sendiri. Ketimpangan kekuasaan tersebut kemudian cenderung dimanfaatkan untuk mengeksploitasi usaha yang lemah.

Nurul Widyaningrum menyatakan terdapat 2 (dua) pola eksploitasi yang terjadi pada rantai hulu hilir Usaha Mikro, Kecil dan Menengah.Pola pertama adalah 
eksploitasi yang terjadi terhadap kelompok lebih miskin melalui penciptaan ketergantungansecara ekonomi maupun secara sosial.Kemiskinan dan kerentanan kelompok Usaha Mikro, Kecil dan Menengah salah satunya ditandai oleh ketidakcukupan pendapatan mereka dari satu sumber penghasilan saja untuk memenuhi kebutuhan sehari-hari. Ketidakcukupan pendapatan ini yang kemudian menyebabkan rumah tangga Usaha Mikro, Kecil dan Menengah harus mencari sumber penghasilan lain di luar usaha yang digeluti oleh mereka. Selain itu,ketidakcukupan penghasilan tersebut juga membuat rumah tangga itu tidak memiliki tabungan maupun bentuk investasi yang dapat digunakan sebagai cadangan dihari-hari mendatang pada saat terjadi guncangan dalam rumah tangga mereka, sehingga harus mencari tambahan penghasilan maupun pinjaman untuk dapat menutupi pengeluaran ekstra tersebut.

Sementara pola kedua adalah pola eksploitasi yang terjadi melalui penciptaan struktur pasar yang monopolitis (penjual tunggal) atau monopsonistis (pembeli tunggal) atau penuh dengan perilaku mafia, sehingga terjadi penekanan melalui mekanisme penentuan harga dan penyediaan barang secara sepihak.Monopoli dan perilaku mafia yang ada pada rantai perdagangan ditandai dengan adanya sekelompok pelaku yang menguasai jalur pengangkutan produk serta hubungan yang erat dengan pelaku pasar akhir yang menyebabkan pelaku lain sulit untuk masuk.

Dalam kaitannya dengan pengadaan barang/jasa pemerintah melalui metode $e$ purchasing yang tidak memberikan pembatasan nilai pekerjaan, maka tentunya PPK atau Pejabat Pengadaan akan dituntut untuk memperoleh barang/jasa yang penawarannya di dalam katalog elektronik terendah/termurah. Hal ini dikarenakan tuntutan untuk melakukan penghematan anggaran negara yang dipergunakan.Pelaku usaha yang menjalin kerja sama dengan LKPP terhadap produk yang dimuat di dalam katalog elektronik, mayoritas ialah perusahaanperusahaan besar yang memiliki kemampuan sumber daya di atas kemampuan Usaha Mikro, Kecil dan Menengah.

Perlindungan hukum adalah suatu perbuatan dalam rangka melindungi subjeksubjek hukum dengan norma-norma atau peraturan perundang-undangan yang berlaku (hukum positif) dan pelaksanaannya dapat dipaksakan dengan suatu sanksi.Dengan menggunakan teori perlindungan hukum, seharusya negara dapat memberikan perlindungan kepada masyarakat.Sebagai bentuk perlindungan hukum, negara dituntut untuk bisa menjamin setiap warga negara mendapatkan hak-hak yang dapat memberikan kepastian hukum serta melindungi subjeksubjekhukum dengan norma-norma atau peraturan perundang-undangan yang berlaku (hukum positif) dan pelaksanaannya dapat dipaksakan dengan suatu sanksi.

Dalam kaitannya dengan pengadaan barang/jasa pemerintah, negara wajib membuat peraturan yang memberikan kesempatan sebesar-besarnya kepada usaha mikro, kecil dan menengah untuk mengukuti pengadaan barang/jasa pemerintah dengan sistem e-purchasing dengan jalan membatasi perusahaan dengan 
klasifikasi besar dapat terlibat dalam pengadaan barang/jasa pemerintah dengan sistem e-purchasing sampai dengan batas nilai tertentu.

Sebagai bentuk perlindungan bagi Usaha Mikro, Kecil dan Menengah untuk berkontribusi dalam pengadaan barang/jasa pemerintah, seharusnya pemerintah yang diwakili oleh Lembaga Kebijakan Pengadaan Barang/Jasa Pemerintah sebagai lembaga yang memiliki otoritas membuat regulasi tentang pengadan barang/jasa pemerintah, membuat pengaturan yang memberikan batasan nilai tertentu yang mewajibkan bagi setiap instansi pemerintah yang menggunakan metode $e$-purchasing, untuk menggunakan produk/jasa dari pelaku - pelaku Usaha Mikro, Kecil dan Menengah. Berikan kesempatan kepada sesama Usaha Mikro, Kecil dan Menengah untuk bersaing dari sisi kualitas dan harga barang/jasa yang mereka tawarkan tanpa harus melibatkan pelaku usaha besar.

Perkembangan usaha rakyat tidak akan terlepas dari persoalan politik, ekonomi dan hukum. Persoalan politik berkaitan dengan praktik kehidupan berbangsa dan negara oleh pemerintah demokrasi, persoalan ekonomi dalam upaya menata dan meningkatkan kesejahteraan rakyat melalui kegiatan ekonomi yang baik serta persoalan hukum untuk mencapai tujuan nasional yang dicita-citakan. Semua saling bersinergi (berkaitan) dalam segenap aspek persoalan bangsa dan negara yang mengalami reformasi menuju masa depan yang lebih baik.

Melihat begitu hegemoniknya proses liberalisasi ekonomi, maka diperlukan perlindungan agar Usaha Mikro, Kecil dan Menengah tetap berkembang dan memilki daya saing. Kurangnya perlindungan hokum terhadap Usaha Mikro, Kecil dan Menengah, membuat Usaha Mikro, Kecil dan MenengahIndonesia mengalami kesulitan dalam berkembang. Sayangnya, fakta tersebut seringkali malah disalahpahami Pemerintah, dunia usaha dan masyarakat. Modal yang terbatas, kualitas SDM, kelemahan penguasaan teknologi malah dilihat sebagai kekurangan Usaha Mikro, Kecil dan Menengah, ketimbang dilihat sebagai akibat yang timbul dari tidak adanya perlindungan (protection) dan pemberdayaan (empowerment) yang memadai. Padahal, siapapun tahu jika kebijakan politk pemerintah secara makro seringkali salah arah dan tidak tepat sasaran dan kurang melindungi Usaha Mikro, Kecil dan Menengah dari persaingan bisnis.

Apabila Usaha Mikro, Kecil dan Menengah tidak diberikan perlindungan hukum oleh pemerintah, maka dapat dipastikan Usaha Mikro, Kecil dan Menengah tidak dapat berkembang. Dalam arti bahwa usaha kecil tidak dapat berkembang dalam posisi berdiri dama tinggi, duduk sama rendah, dengan usaha yang jauh lebih besar. Perlindungan menjadi kata kunci penting bagi usaha kecil, mengingat tantangan liberalisasi ekonomi yang semakin besar.

Prinsip perlindungan dalam hukum ekonomi terutama kegiatan Usaha Mikro, Kecil dan Menengah adalah mencakup :

a. Prinsip ekonomi dalam UUD 1945, prinsip ini seperti dirumuskan oleh the founding father atau pembentuk UUD 1945 yang telah memikirkan dengan matang bangunan ekonomi bagi bangsa Indonesia, melalui prinsip ekonomiguna mencapai tujuan nasional yaitu masyarakat adil dan makmur. 
Artinya kemakmuran rakyat dapat diperoleh melalui kegiatan ekonomi yang betul-betul sehat dan jauh dari praktik-praktik persaingan usaha tidak sehat;

b. Prinsip perlindungan kepentingan nasional. Ketentuan dalam Pasal 33 ayat (2) dan (3) UUD 1945 diatur mengenai penguasaan negara atas cabang-cabang produksi yang memenuhi kepentingan nasional. Penguasaan sebagai bentul daripada kepentingan nasional. Penguasaan Negara atas cabang-cabang produksi tersebut didasarkan pada upaya untuk dapat melindungi kepentingan rakyat banyak guna memenuhi kebutuhan primer dan perilaku pengusaha tidak baik yang menguasai sumber daya di dalam bentuk monopoli. Perlu dikemukakan bahwa prinsip perlindungan kepentingan nasional yang ditetapkan berarti ada kepentingan umum yang tidak boleh bersifat kontraproduktif terhadap asas kebebasan berkontrak. Artinyademi kepentingan umum dan nasional, ruang gerak kebebasan berkontrak bagi para pelaku usaha tidak semakin sempit dalam kegiatan bisnis. Apabila ini terjadi, sama saja tidak ada pengakuan negara terhadap asas kebebasan berkontrak, sekalipun untuk perlindungan kepentingan umum/nasional, karena mematikan pengusaha dalam berbisnis;

c. Prinsip perlindungan dalam hokum internasional dan hukum perdata. Selain aspek hukum nasional yang berupaya meningkatkan kemampuan daya saing produk barang dan jasa dalam negeri, perekonomian nasional juga harus memperhatikan prinsip perlindungan hukum internasional. Perlindungan iniakan mempengaruhi reputasi ekonomi dan perlakuan negara lain terhadap kegiatan pemasaran produk-produk Indonesia, baik di dalam maupun luar negeri. Perlindungan hukum internasional dan hukum perdata internasional dalam kerangka perdagangan antar negara melalui pelbagai sarana transportasi dan komunikasi saling menghormati berdasarkan perjanjian internasional dan prinsip pacta sunt servanda, yaitu perjanjian yang telah disepakati berlaku sebagai undang-undang bagi pihak yang menyelenggarakan perjanjian;

d. Prinsip perlindungan bagi golongan ekonomi lemah. Berbagai ketentuan yang mengatur pengembangan Usaha Mikro, Kecil dan Menengah selama ini menunjukkan perhatian pemerintah terhadap pengusaha kecil. Di antara ketentuan tersebut adalah Undang-Undang Nomor 9 tahun 1995 tentang Usaha Kecil juncto Undang-Undang Nomor 20 tahun 2008 tentang Usaha Mikro Kecil dan Menengah sebagai upaya perlindungan hukum untuk pengusaha kecil, sehingga pembinaan pasar bagi usaha kecil harus merupakan suatu sistem terpadu, karena pengembangannya tergantung dari interaksi unsur organisasi dari para pengusaha kecil dan komponen pendukung dari kebijakan eknomi pemerintah, usaha menengah dan usaha besar yang dapat saling membantu dan mempengaruhi;

e. Prinsip perlindungan kepentingan nasional dalam GATT. Kepentingan ekonomi nasional suatu negara perlu dilindungi dari praktik bisnis curang, baik yang dilakukan oleh pengusaha di dalam negeri maupun pengusahaasing. Begitu juga oleh Negara industri maju terhadap negara berkembang melalui kebijakan ekonomi yang dapat menghalangi masuknya barang ekspor dan impor ke negara tersebut. Prinsip dan perlindungan kepentingan nasional ini tetap diakui di dalam ketentuan GATT sebagai bentuk pengecualian dari 
prinsip umum terhadap industri dan negara tertentu pada kegiatan ekonomi dunia;

f. Prinsip persaingan usaha yang sehat. Kegiatan bisnis modern yang ketat dan penuh persaingan menimbulkan perlakuan kurang adil dan sering dialami oleh pihak ekonomi lemah. Pengusaha yang kuat danserakah dengan berbagai cara berusaha untuk menguasai pasar nasional, regional dan internasional. Praktik curang tidak hanya dilakukan berdasarkan perbuatan melawan hukum (onrechtmatige daad) dalam hukum perdata,45 akan tetapi juga berupa penyalahgunaan hak yang merugikan bagi pengusaha dan negara-negara berkembang mengekspor produk berupa bahan mentah, barang setengah jadi atau kerajinan. Bentuk persaingan curang (unfair competition) tidak dapat ditolerir dan perlu dicegah dan dikurangi di dalam kegiatan bisnis, baik melalui peraturan perundang-undangan maupun dalam bentuk putusan hakim dan kebijakan ekonomi pejabat eksekutif. Klausula kontrak bisnis yang curang secara nyata melahirkan keuntungan tidak wajar atau tidak sebanding besarnya pada satu pihak. Sebaliknya, pihak-pihak yang lain karena ketidaktahuan atau kelemahan tertentu yang dihadapinya semakin terdesak kedudukan ekonominya dalam angka persaingan pasar

Berdasarkan kebijakan yang ada, maka yang terpenting adalah penciptaan iklim usaha kecil. Hal ini dirumuskan Pasal 8 huruf G Undang-Undang Nomor 9 Tahun 1995 tentang Usaha Kecil dan Undang-Undang Nomor 20 Tahun 2008 tentang Usaha Mikro, Kecil, dan Menengah yang dilakukan melalui penetapan peraturan perundang-undangan dan kebijakan perlindungan bagi ekonomi lemah. Namundalam undang-undang tersebut tidak ditegaskan tentang bentuk peraturan perundang-udangan yang harus dikeluarkan untuk dapat mengatur dan melaksanakan lebih lanjut mengenai perlindungan yang harus diberikan kepada Usaha Mikro, Kecil dan Menengah.

\section{E. Kesimpulan}

Dari hasil penelitian ini dapat ditarik kesimpulan sebagai berikut :

1. Kekurangan dalam hal pemodalan, tenaga kerja dan bahan baku membuat Usaha Mikro, Kecil dan Menengah akan sangat sulit bersaing dengan pebisnis raksasa dalam hal penentuan harga suatu produk. Kemampuan sumber daya yang kuat dari perusahaan-perusahaan besar, memberikan implikasi terhadap rendahnya harga yang ditawarkan perusahaan-perusahaan besar tersebut. Dalam kaitannya dengan pengadaan barang/jasa pemerintah melalui metode $e$ - purchasing, Peraturan Presiden Nomor 16 Tahun 2018 tidak memberikan pembatasan nilai pekerjaan, maka tentunya PPK atau Pejabat Pengadaan akan dituntut untuk memperoleh barang/jasa yang penawaran terdendah di dalam katalog elektronik. Hal ini dikarenakan tuntutan untuk melakukan penghematan anggaran negara yang dipergunakan. Karena tidak adanya peraturan yang membatasi usaha besar untuk terlibat dalam pengadaan barang/jasa pemerintah dengan sistem e-purchasing, membuat Usaha Mikro 
Kecil dan Menengah kesulitan untuk dapat menjadi penyedia dalam proses pengadaan barang/jasa pemerintah.

2. Apabila Usaha Mikro, Kecil dan Menengah tidak diberikan perlindungan hukum oleh pemerintah, maka dapat dipastikan Usaha Mikro, Kecil danKeterbatasan menemukan literatur-literatur yang berkaitan dengan judul penelitian ini.

3. Lembaga Kebijakan Pengadaan Barang/Jasa Pemerintah sebagai otoritas yang memiliki kewenangan dalam merusmuskan regulasi terkait dengan pengadaan barang dan jasa pemerintah, seharusnya dapat melahirkan peraturan-peraturan yang memberikan ruang yang seluas-luasnya bagi Usaha Mikro, Kecil dan Menengah untuk dapat saling bersaing dengan jalan membatasi pelaku usaha besar untuk bisa mengikuti pengadaan barang/jasa pemerintah dengan metode $e$ - purchasing sampai dengan nilai tertentu. 


\section{DAFTAR PUSTAKA}

\section{Buku}

Achmad Ali, Menguak Tabir Hukum (Suatu Kajian Filosofis dan Sosiologis), Jakarta, PT. Gunung Agung Tbk., 2002.

Ade Komarudin, Politik Hukum Integratif Usaha Mikro, Kecil dan Menengah, Kebijakan Negara Membuat Usaha Mikro, Kecil dan Menengah Maju dan Berdaya Saing, Jakarta: PT Semesta Rakyat Merdeka, 2014.

Adrian Sutedi, Aspek Hukum Pengadaan Barang \& Jasa dan Berbagai Permasalahannya.Ed. 2. Jakarta, Sinar Grafika, 2012

Atmosudirjo, Prajudi, Hukum Administrasi Negara, Jakarta, Ghalia, Indonesia, 1981

Budiono Kusumohamidjojo, yang dikutip Ridwan HR, Hukum Administrasi Negara, Jakarta: RajaGrafindo Persada, 2008

Djumialdji, Hukum Bangunan Dasar-Dasar Hukum Dalam Proyek dan Sumber DayaManusia, Jakarta, Rhineka Cipta,1996

Edi Suharto, Membangun Masyarakat Memberdayakan Masyarakat, Kajian Strategis Pembangunan Kesejahteraan Sosial dan Pekerjaan Sosial, Bandung, PT. Refika Aditam, 2007

Esmi Warassih, Pranata Hukum Sebuah Telaah Sosiologis, PT. Suryandaru Utama, Semarang, 2005

H. Hikmat, Strategi Pemberdayaan Masyarakat, Bandung, Humaniora Utama Press, 2010

Hardjowijono, Prinsip Dasar Pengadaan Barang/Jasa Publik di Indonesia.Jakarta, Indonesia Procurement Watch, 2010

Isbandi Rukminto Adi..Intervensi komunitas pengembangan masyarakat sebagai upaya pemberdayaan masyarakat. Jakarta, Raja Grafindo Persada, 2008

Joko Widodo, Analisis Kebijakan Publik Konsep dan Aplikasi Analisis Proses Kebijakan Publik, Malang, Bayumedia Publising, 2007

Julius Bobo, Transformasi Ekonomi Rakyat, Jakarta, Cidesindo, 2003

Kusmuljono, Menciptakan kesempatan rakyat berusaha. Bogor, IPB Press, 2009 
M. Oos. Anwas, Pemberdayaan Masyarakat di era Global, Bandung, Alfabeta, 2013

Mohammad Hafzah, Kemitraan usaha: strategi dan konsepsi, Jakarta, Pustaka Sinar Harapan, 1999

Much.Nurachmad, Buku Pintar Pengadaan Barang/Jasa Pemerintah. Jakarta, Visimedia, 2011

Musa Hubeis, Prospek Usaha Kecil Dalam Wadah Inkubator Bisnis, Jakarta, Ghalia Indonesia, 2009

Nurul Widyaningrum, Pola-Pola Eksploitasi Terhadap Usaha Kecil, Yogyakarta, Yayasan Akatiga, 2003

Peter Mahmud Marzuki, Penelitian Hukum. Jakarta, Kencana Prenada, 2005

Philipus M. Hadjon, Perlindungan Hukum Bagi Rakyat Indonesia, Surabaya, PT. Bina Ilmu, 1987

R. Suroso, Pengantar Ilmu Hukum, Jakarta, Penerbit Sinar Grafika, 2002

Sudikno Mertokusumo, Mengenal Hukum (Suatu Pengantar), Yogyakarta: Liberty, 1991

Tulus T.H Tambunan, Usaha Kecil dan Menengah di Indonesia Beberapa Isu Penting, Jakarta, Salemba Empat, 2002

Tulus T.H Tambunan, Usaha Mikro Kecil Dan Menengah di Indonesia, Jakarta, Ghalia Indonesia, 2009

W.J.S. Poerwadarminta, Kamus Umum Bahasa Indonesia, Cetakan IX, Jakarta, Balai Pustaka, 1986

Zuhal, Knowledge and Innovation Platform Kekuatan Daya Saing, Jakarta, Gramedia, 2010

\section{Jurnal}

Ari Ratna Kurniastuti, "Perlindungan Hukum Usaha Mikro Kecil Menengah (Usaha Mikro Kecil dan Menengah) Dari Dampak Adanya Perjanjian Asean-China Free Trade Area (Acfta)", Jurnal Arena Hukum, Vol. 6, No. 2, 2013.

Arief Rahmana, Peranan Tekhnologi Informasi dalam Peningkatang Daya Saing Usaha Kecil Menengah, Seminar Teknologi Informasi (SNATI), Yogyakarta, ISSN: 1907-5022, 2009 
Bismar Nasution, Hukum Perusahaan, Program Magister Hukum, Program Pascasarjana USU, Medan, 2003,

Bismar Nasution, Mengkaji Ulang Sebagai Landasan Pembangunan Ekonomi, Pidato pada Pengukuhan sebagai Guru Besar USU, Medan, 2004

Cornelis Rintuh dan Miar, Kelembagaan dan Ekonomi Rakyat, Edisi Pertama, Yogyakarta, Fak. Ekonomi UGM, 2005

Denny Sanjaya, Analisis Yuridis Pengadaan Barang/Jasa Yang Dilakukan Dinas Pendidikan Kota Tanjungbalai Ditinjau Dari Peraturan Presiden Nomor 54Tahun 2010 Tentang Pengadaan Barang/Jasa Pemerintah,Jakarta, Jurnal Hukum Ekonomi, 2013

Departemen Koperasi, PDB, Investasi, Tenaga Kerja, Nilai Ekspor UKM di Indonesia.Jakarta, Depkop. 2008

Glen Glenardi, Peran Perbankan dalam Pengembangan Keuangan Mikro, Jakarta,Diskusi kelompok C2 Temu Nasional Bazar Pengembangan Mikro, 2002

I Dasi Astawa Nengah.Pemberdayaan UKM dan Koperasi di Kabupaten Jembrana Provinsi Bali. Jurnal Ekonomi/Tahun XXI, No.01, 2007

R. Marhadi, Ekonomi kerakyatan keuanggulan kelemahan dan prospek ke depan Ekonomi kerakyatan dalam kancah globalisasi. Jakarta, Deputi Bidang Pengkajian Sumberdaya usaha mikro kecil dan menengah, Kementerian Koperasi dan Usaha kecil dan menengah RI, 2003

Setiono, Hukum dan Kebijakan Publik, Bahan Matrikulasi, Program Magister Ilmu Hukum Fakultas Hukum Universitas Sebelas Maret, Surakarta, 2008

SMERU.Upaya penguatan usaha mikro dalam rangka peningkatan ekonomi perempuan (Sukabumi, Bantul, Kebumen, Padang, Surabaya, Makassar). Jakarta, Kementerian Pemberdayaan Perempuan RI, 2003

Sukarmi, Perlindungan Sosial Desain Industri Bagi Usaha Mikro, Kecil dan Menengah Yang Berkeadilan Sosial, Jurnal Pembaharuan Hukum, Vol. 3, No. 1 (Apr, 2016)

Wibowo, Agung, Konsep Dasar \& Prosedur Pengadaan Barang/Jasa, Semarang, Program Studi Magister Manajemen Universitas Diponegoro, 2002 


\section{Internet}

Dhaniswara K. Harjono, UMKM Butuh Perlindungan Hukum Dalam Menghadapi MEA, http://www.hukumonline.com/berita/baca/lt54291034f072b/umkmbutuh-perlindungan-hukum-dalam-menghadapi-mea-2015, diakses 12 Agutus 2018.

Muji Santoso, Cara Mudah Memahami Pengadaan Barang dan Jasa.www.mujisantoso.blogspot.com, diakses tanggl 2 September 2018.

\section{Peraturan Perundang-undangan}

Undang-Undang Dasar Negara Republik Indonesia tahun 1945.

Undang-Undang Nomor 39 Tahun 1999 Tentang Hak Asasi Manusia.

Undang-Undang Nomor 11 Tahun 2008 Tentang Transaksi Elektronik

Undang-Undang Republik Indonesia Nomor 20 Tahun 2008 Tentang Usaha Mikro Kecil dan Menengah

Peraturan Presiden Nomor 54 Tahun 2010 tentang Pengadaan Barang/Jasa Pemerintah

Peraturan Presiden Nomor 16 Tahun 2018 tentang Pengadaan Barang/Jasa Pemerintah 